\title{
Physical, chemical and microbiological aspects during the dry and rainy seasons in a pond covered by macrophyte used in aquaculture water supply
}

Aspectos físico-químicos e microbiológicos nas estaçóes de seca e chuva em viveiro coberto por macrófitas usado no abastecimento de água para aquicultura

\section{Samuel Generoso Dias ${ }^{1}$ and Lúcia Helena Sipaúba-Tavares ${ }^{2}$}

${ }^{1}$ Laboratório de Limnologia e Produção de Plâncton, Programa de Pós-graduação em Microbiologia

Agropecuária, Centro de Aquicultura, Universidade Estadual Paulista - UNESP,

CEP 14884-900, Jaboticabal, SP, Brazil

e-mail: samueldias@hotmail.com.br

${ }^{2}$ Laboratório de Limnologia e Produçáo de Plâncton, Centro de Aquicultura,

Universidade Estadual Paulista - UNESP, CEP 14884-900, Jaboticabal, SP, Brazil

e-mail:sipauba@caunesp.unesp.br

\begin{abstract}
Aim: The water quality of a pond covered by macrophytes and used as a water supply for aquaculture was evaluated during the dry and rainy seasons; Methods: Six points were established for water sampling, at water inflow and outflow. Samplings were carried out monthly between June 2008 and May 2009; Results: Inflow points $\mathrm{P}_{1}, \mathrm{P}_{2}$ and $\mathrm{P}_{3}$ in the pond had higher nutrient concentrations and high trophic rates. Moreover, capybaras in the area caused sediment suspension and an increase in fecal coliforms. There was significant difference $(\mathrm{p}<0.05)$ in the concentrations of nutrients in water between the dry and rainy seasons. The outflow of water caused by rain carried the material around the pond directly into the water; Conclusions: The system studied was influenced by rain and lack of adequate management of the surrounding area. Water quality was deteriorated by increase in nutrient concentrations, fecal coliforms and reduction of dissolved oxygen in the water during the rainy season. This was due to allochthonous material from the area surrounding the pond that affected negatively the supply system.
\end{abstract}

Keywords: water quality, fecal coliforms, rainfall, trophic state, aquaculture.

Resumo: Objetivo: O objetivo deste estudo foi avaliar durante as estaçóes seca e estação chuvosa a qualidade da água de um viveiro, coberto por macrófitas, utilizado como sistema de abastecimento de água para aquicultura; Métodos: Foram estabelecidos 6 pontos para a coleta das amostras de água na superfície do viveiro, envolvendo entradas e saídas da água. As coletas foram realizadas mensalmente entre junho de 2008 e maio de 2009; Resultados: Os pontos $\mathrm{P}_{1}, \mathrm{P}_{2}$ e $\mathrm{P}_{3}$ devido à entrada de água no viveiro apresentaram maiores concentraçóes de nutrientes com elevado estado trófico e, a entrada de capivaras nestes locais promoveu a suspensão do sedimento e aumento de coliformes fecais. Há significativas diferenças $(p<0,05)$ nas concentraçóes de nutrientes na água entre seca e chuva, com o escoamento de água gerado pela precipitação carreando material do entorno do viveiro para a água; Conclusóes: $\mathrm{O}$ sistema estudado sofre influência direta da precipitaçáo e da ausência de manejo adequado da área do entorno. Durante a estaçáo chuvosa a qualidade da água ficou comprometida com aumento da concentração de nutrientes, coliformes fecais e redução do oxigênio dissolvido na água, devido ao material alóctone proveniente da área ao redor do viveiro, afetando negativamente o sistema de abastecimento.

Palavras-chave: qualidade de água, coliformes fecais, precipitação, estado trófico, aquicultura. 


\section{Introduction}

Limnological studies are important to understand aquatic environments foregrounding the adequate use of water. They provide knowledge that would produce technologies for water management and guarantee water supply in adequate conditions for aquaculture. Since water resources have significant ecological, economical and social importance, the quality of aquatic ecosystems affects society as a whole (Calijuri et al., 2008).

The protection of water bodies involves three basic aspects: protection of water sources, water treatment and the maintenance of the integrity of the water environments (Plummer and Long, 2007). The main water sources for the maintenance of aquaculture tanks and ponds should not be negatively affected by floods from the surrounding areas (Sipaúba-Tavares et al., 2007).

Cattle-raising activities in areas close to aquaculture systems affect water quality and modify the quantity of nutrients in the water and sediments. They actually indicate the need for riparian vegetation that would effectively protect the environment against runoff water from agricultural areas and pastureland (Meador and Goldstein, 2003). Rainfall and surface water discharge also contribute towards the accumulation of allochthonous material since they carry away substances around the basin and cause changes in the water quality of the receiving water bodies (Neill et al., 2004).

Environments which receive water inflow from agricultural areas have high nutrient levels, high chlorophyll-a rates and great amount of suspended particles (Silva and Sacomani, 2001; Brainwood and Maheshwari, 2004). Eutrophication of water bodies is frequently the outcome of nutrient accumulations from soil (Taguchi and Nakata, 2009) and in spite of great progress in naturalizing the phenomenon, the reversion of the process is still a challenge. The best strategy lies in conservation rather than in the restoration of the environment (Suding et al., 2004).

Certain inconveniences in the case of aquatic plants comprise excessive growth and natural death with a consequent rise in nutrient rates by decomposition. However, proper management provides filtration, absorption and biodegradation and contributes towards an improvement of water quality in eutrophicating environments (Ruggiero et al., 2003; Joniak et al., 2007; Lishawa et al., 2010).

Current analysis evaluates the effect of naturally grown macrophytes in a pond with water supplying a system for the breeding of aquatic organisms. It also determines the effect of the plants on the water quality by comparing water inflow and outflow. Further, it investigates whether the pond may adequately supply water to aquaculture ponds during the dry and rainy seasons.

\section{Methods}

\subsection{Study area and sampling period}

Current research was conducted in a pond at the Aquaculture Farm $\left(21^{\circ} 15^{\prime} \mathrm{S}\right.$ and $\left.48^{\circ} 18^{\prime} \mathrm{W}\right)$, with continuous flow of water, $3,800 \mathrm{~m}^{2}$ area and an approximately 14-day residence time (SipaúbaTavares et al., 1991).

The pond receives water directly from several sources and is practically covered with macrophytes, mainly Salvinia auriculata Aublet and Eichhornia azurea (Sw.) Kunth. The pond had already been used for fish breeding, although some years ago it became a water reservoir to supply the breeding system of water organisms of the Aquaculture Farm. Some fish species, such as Oreochromis niloticus (tilapia) and Astyanax sp. (lambari), are still extant in the pond and survive by feeding on its aquatic biota (Sipaúba-Tavares, 2006).

Water samples were collected at the surface $(0.10 \mathrm{~m}$ depth $)$ at six points: $\mathrm{P}_{1}=$ close to the water sources (water inflow from the source and from runoff water); $\mathrm{P}_{2}-\mathrm{P}_{3}=$ pond sides and inflow points of runoff water during the rainy season; $\mathrm{P}_{4}=$ the deepest and most central point in the pond; $\mathrm{P}_{5}-\mathrm{P}_{6}=$ outflow. Points $\mathrm{P}_{1}, \mathrm{P}_{2}$ and $\mathrm{P}_{3}$ are also the inflow points of the capybaras (Hidrochoerus hidrochoeris, Linnaeus, 1766) in the supply pond (Figure 1). The climate, according to Köpen's classification is Cwc (Peel et al., 2007), subtropical, relatively dry during the winter (June to September) and rainy in the summer (December to March), with mean yearly temperature of $22{ }^{\circ} \mathrm{C}$, rainfall $1,424.6 \mathrm{~mm}$ and mean altitude $605 \mathrm{~m}$.

\subsection{Physical, chemical and microbiological parameters}

Samples for abiotic parameters and Escherichia coli were undertaken monthly between June 2008 and March 2009. Temperature, electrical conductivity and $\mathrm{pH}$ were measured by multiprobe HORIBA U-10 water quality check and dissolved oxygen was determined by oxygen meter YSI-55. Nitrite, nitrate, orthophosphate, total phosphorus and ammonia were determined 


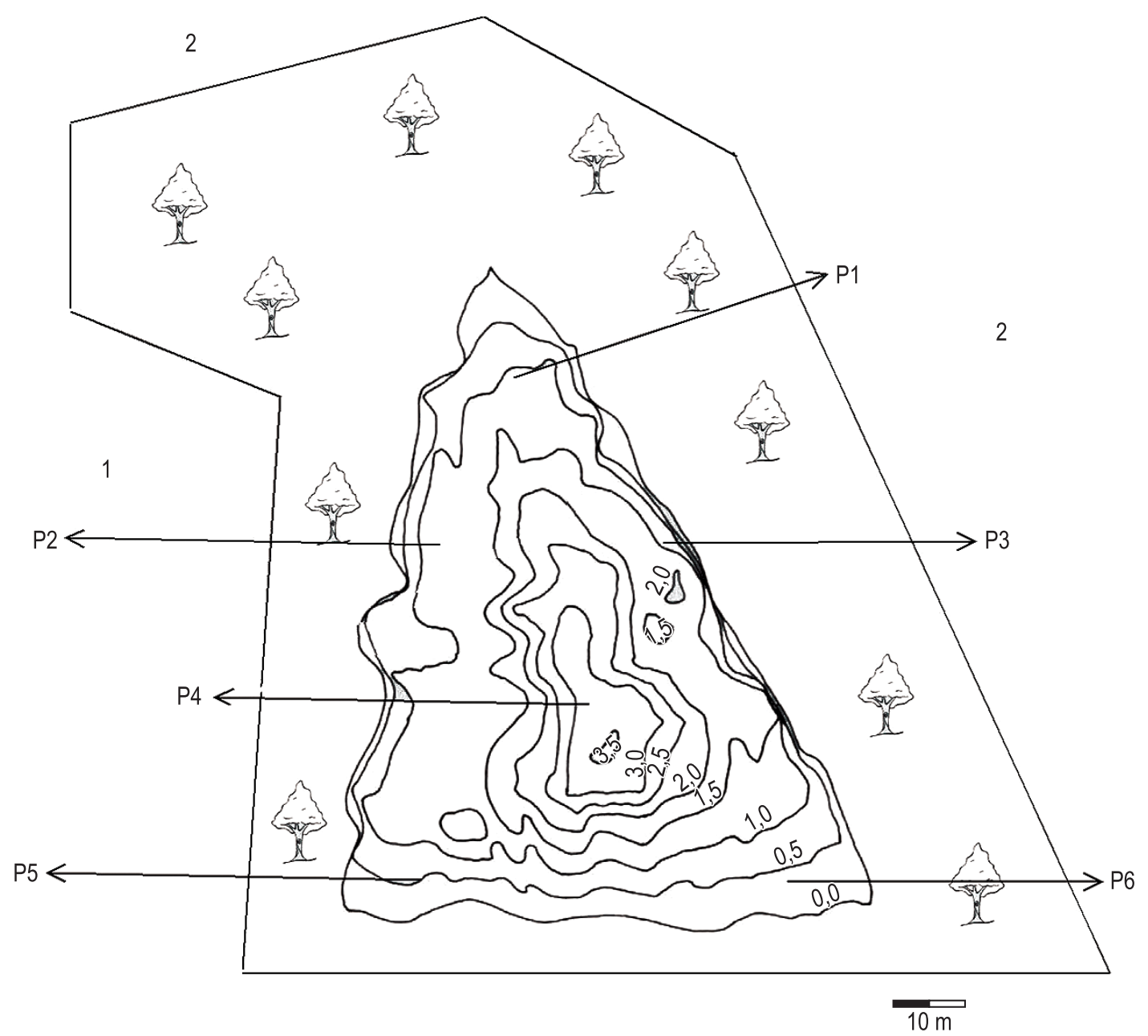

Figure 1. Cross-section of the supply pond under analysis, where: $\mathrm{P}_{1}-\mathrm{P}_{6}=$ sampling points, 1 = cattle-raising section and 2 = sheep-breeding section (adapted from Sipaúba-Tavares et al., 1991).

according to Golterman et al. (1978) and Koroleff (1983). Chlorophyll-a was evaluated according to Nusch (1980) and 5-day biochemical oxygen demand and suspended solids were determined according to Boyd and Tucker (1992). Soil analysis was undertaken for phosphorus and organic matter (OM) according to methods described by Andersen (1976), while results of fecal coliforms and Escherichia coli were obtained by multiple tube fermentation procedure as MPN/100 mL index, according to Greenberg et al. (1992). Water transparency was estimated with a Secchi disk and data on rainfall rates (monthly means) were supplied by the Aquiculture Climatology Station of the Universidade Estadual Paulista in Jaboticabal SP Brazil.

\subsection{Trophic State Index}

Trophic State Index (TSI), developed by Carlson, with modifications by Toledo Junior et al. (1983), was used to monitoring the trophic level. TSI is the mean obtained from the sum of chlorophyll-a trophic state index (CTSI) and phosphorus trophic state index (PTSI).

\subsection{Statistical analysis}

The non-parametric Mann-Whitney test (U test) compared physical and chemical parameters and coliform with climatic seasons (dry and rainy season) and points (inflow and outflow. KruskalWallis test was employed to compare sampling points in each season (Siegel, 1975). Results were evaluated by data multivaried analysis. Principal Components Analysis (PCA) was used to reduce the dimensionality of the limnological variables in relation to sampling points (Manly, 1986). Points were grouped by cluster analyses during the dry and rainy seasons to obtain similarity among the six points (Zar, 1999). Co-variance matrix was employed and data were transformed by range 
variation amplitude. All analyses were carried out by Statistica 8.0.

\section{Results}

Similarity analysis for physical, chemical and microbiological parameters showed the formation of two groups during the rainy and dry seasons. $\mathrm{P}_{3}$, $\mathrm{P}_{4}, \mathrm{P}_{2}$ and $\mathrm{P}_{1}$ points during the rainy season were markedly different from $\mathrm{P}_{6}$ and $\mathrm{P}_{5}$, due to the direct influence of nutrient and organic matter inflow. $\mathrm{P}_{3}$, $\mathrm{P}_{2}$ and $\mathrm{P}_{1}$ were different from $\mathrm{P}_{6}, \mathrm{P}_{5}$ and $\mathrm{P}_{4}$ during the dry season (Figure 2).

Principal Components Analysis, conducted with the limnological variables obtained during the monitoring period, showed that the first three components concentrated $87 \%$ of the available original information (Figure 3).

Axis $1(45 \%)$ showed a sharp opposition between points $\mathrm{P}_{1}, \mathrm{P}_{2}$ and $\mathrm{P}_{3}$ during the rainy season and between points $\mathrm{P}_{4}, \mathrm{P}_{5}$ and $\mathrm{P}_{6}$ during the dry season, with greater and lesser load of nutrients, organic matter and fecal coliforms in the environment (Figure 3a). During the dry season, points $\mathrm{P}_{4}, \mathrm{P}_{5}$ and $\mathrm{P}_{6}$ on axis 1 were greatly related to transparency and dissolved oxygen, whereas during the rainy season $\mathrm{P}_{1}, \mathrm{P}_{2}$ and $\mathrm{P}_{3}$ were related to nitrite, $\mathrm{pH}$, rainfall, temperature, orthophosphate, ammonia, total phosphorus, chlorophyll-a, $\mathrm{BOD}_{5}$, organic matter in the sediment, phosphorus in the sediment, TSS, total coliforms and Escherichia coli (Figure 3).

A sharp opposition between $\mathrm{P}_{4}, \mathrm{P}_{5}$ and $\mathrm{P}_{6}$ during the rainy season and $\mathrm{P}_{1}, \mathrm{P}_{2}$ and $\mathrm{P}_{3}$ during the dry season may be observed on axis 2 (29\%). The points were related to nitrate and TDS during the dry season (Figure 3a). Since $\mathrm{P}_{3}$ on axis 3 was greatly related with electrical conductivity during the dry season (Figure 3b), it should be emphasized that the constant entry of capybaras (Hydrochoerus hydrochaeris) at this point increased the ions in the water because of sediment suspension.

Owing to local climatic conditions, water temperature and mean monthly rainfall were higher during the rainy season and scored a significant difference $(\mathrm{p}<0.05)$ between the dry and rainy seasons $\left(Z^{3}\right)$ (Table 1$)$.

Inflow points $\left(\mathrm{P}_{1}, \mathrm{P}_{2}\right.$ and $\left.\mathrm{P}_{3}\right)$ differed significantly $(\mathrm{p}<0.05)$ from the others during the dry season $\left(Z^{1}\right)$, with higher rates in nitrate, fecal coliforms, E. coli, chlorophyll-a, BOD, TDS and TSS (Table 1).

There was a significant difference $(\mathrm{p}<0.05)$ during the rainy season between the inflow $\left(\mathrm{P}_{1}, \mathrm{P}_{2}\right.$ and $\left.\mathrm{P}_{3}\right)$ and outflow $\left(\mathrm{P}_{5}\right.$ and $\left.\mathrm{P}_{6}\right)$ points $\left(Z^{2}\right)$ for conductivity, nitrate, total phosphorus, orthophosphate, E. coli, total coliforms, $\mathrm{BOD}_{5}$, TDS and TSS (Table 1), with higher concentrations at the inflow points.

There were significant differences $(\mathrm{p}<0.05)$ in temperature, dissolved oxygen, $\mathrm{pH}$, nitrate, nitrite, total phosphorus and orthophosphate during the dry and rainy seasons $\left(\mathrm{U}^{3}\right)$ (Table 1 ). Temperature, $\mathrm{pH}$, concentration of nitrate, nitrite, total phosphorus and orthophosphate water were higher during the rainy season, whereas dissolved oxygen concentration was higher during the dry one $(\mathrm{p}<0.05)$ (Table 1$)$.

Significant differences $(\mathrm{p}<0.05)$ occurred in nitrate concentrations between $\mathrm{P}_{1}$ and $\mathrm{P}_{5}$ during the dry season, with mean concentrations $806.7 \mu \mathrm{g} . \mathrm{L}^{-1}$ and 582.9 $\mu \mathrm{g} . \mathrm{L}^{-1}$ respectively, and between $\mathrm{P}_{3}$ and $\mathrm{P}_{5}$ during the rainy season, with mean concentrations $659.3 \mu \mathrm{g} . \mathrm{L}^{-1}$ and $498.5 \mu \mathrm{g} . \mathrm{L}^{-1}$. During the dry season, $\mathrm{P}_{1}$ and $\mathrm{P}_{6}$ differed in total phosphorus, with mean concentrations $52 \mu \mathrm{g} . \mathrm{L}^{-1}$ and $22.7 \mu \mathrm{g} . \mathrm{L}^{-1}$, respectively, whereas during the rainy season
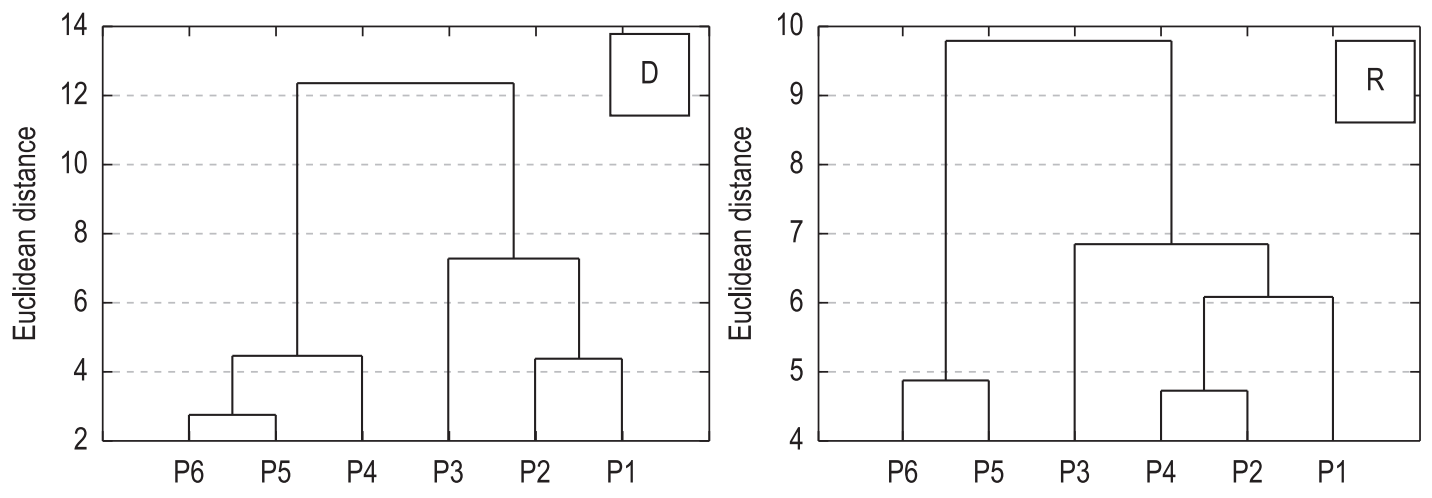

Figure 2. Cluster analyses with average physical, chemical and microbiological parameters at sampling points in the pond; $\mathrm{D}=$ dry season; $\mathrm{R}$ = rainy season. 

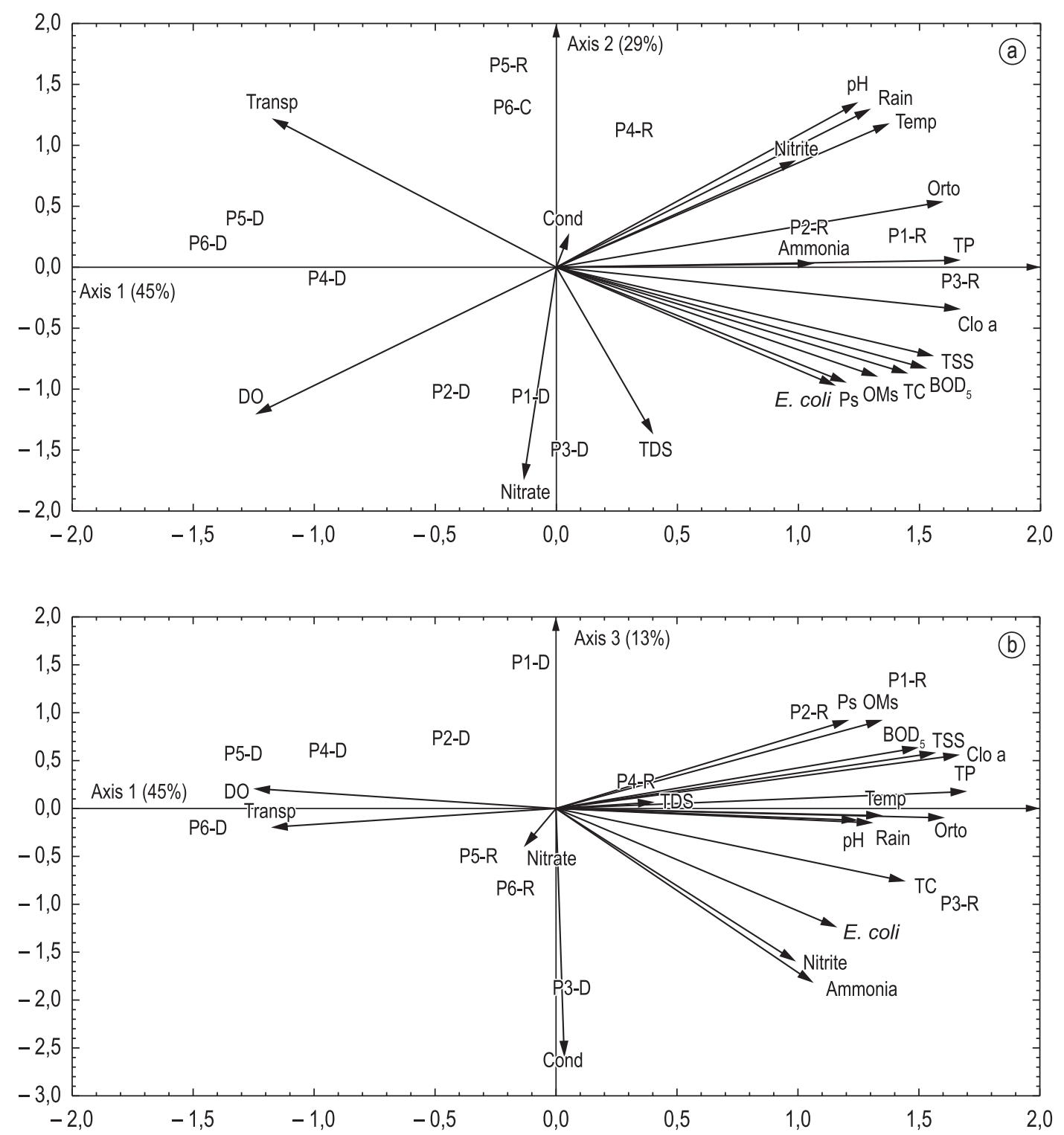

Figure 3. Interpolation of autovalues from the matrix of abiotic and microbiological parameters in the pond, where a) the first two components, b) the first and third components, D = dry, R = rainy, DO = dissolved oxygen, Rain = rainfall, Orto = orthophosphate, Cond = conductivity, OMs = organic matter in the sediment, Ps = phosphorus in the sediment, TC = total coliforms, E. coli = Escherichia coli, TSS = total suspended solids, TDS = total dissolved solids, Temp $=$ temperature, Clo $\mathrm{a}=$ chlorophyll-a, $\mathrm{TP}=$ total phosphorus and Transp $=$ transparency.

differences between $\mathrm{P}_{1}$ and $\mathrm{P}_{5}$ occurred with mean concentrations $66.9 \mu \mathrm{g} . \mathrm{L}^{-1}$ and $38.3 \mu \mathrm{g} . \mathrm{L}^{-1}$ respectively. There was no significant difference for orthophosphate $(\mathrm{p}>0.05)$ among the points (Table 1).

Significant differences $(\mathrm{p}<0.05)$ were detected during the dry season for $E$. coli between $\mathrm{P}_{1}$ and $P_{5}$ and $P_{6}$ (6.6 NMP.mL $L^{-1}, 0.4$ NMP.mL ${ }^{-1}$ and 0.3 NMP. $\mathrm{mL}^{-1}$ respectively). In the case of fecal coliforms, $\mathrm{P}_{1}\left(6.8 \mathrm{NMP} \cdot \mathrm{mL}^{-1}\right)$ differed $(\mathrm{p}<0.05)$ from $\mathrm{P}_{6}\left(0.2\right.$ NMP.mL $\left.L^{-1}\right)$, whereas $\mathrm{P}_{3}$ (12.3 NMP.mL $\left.L^{-1}\right)$ differed $(p<0.05)$ from $P_{5}$
(0.3 NMP.mL $\left.{ }^{-1}\right)$ and $\mathrm{P}_{6}\left(0.2\right.$ NMP.mL $\left.{ }^{-1}\right)$ (Table 1). During the rainy season, significant differences ( $\mathrm{p}<0.05)$ were observed between $E$. coli and fecal coliforms at points $\mathrm{P}_{3}\left(24.8 \mathrm{NMP} \cdot \mathrm{mL}^{-1}\right.$ and 21.1 NMP.mL $\left.L^{-1}\right), \mathrm{P}_{5}\left(0.4\right.$ NMP.mL $L^{-1}$ and 0.5 NMP. $\left.\mathrm{mL}^{-1}\right)$ and $\mathrm{P}_{6}\left(0.5\right.$ NMP. $\mathrm{mL}^{-1}$ and 0.5 NMP.mL ${ }^{-1}$ ) (Table 1).

No significant difference ( $p>0.05)$ was reported for transparency, organic matter and phosphorus in the sediment between seasons and points. $\mathrm{P}_{2}$ had a higher rate in organic matter $(23.6 \%)$ and $\mathrm{P}_{4}$ had a lower one $(9.9 \%)$ (Table 1). Total phosphorus 


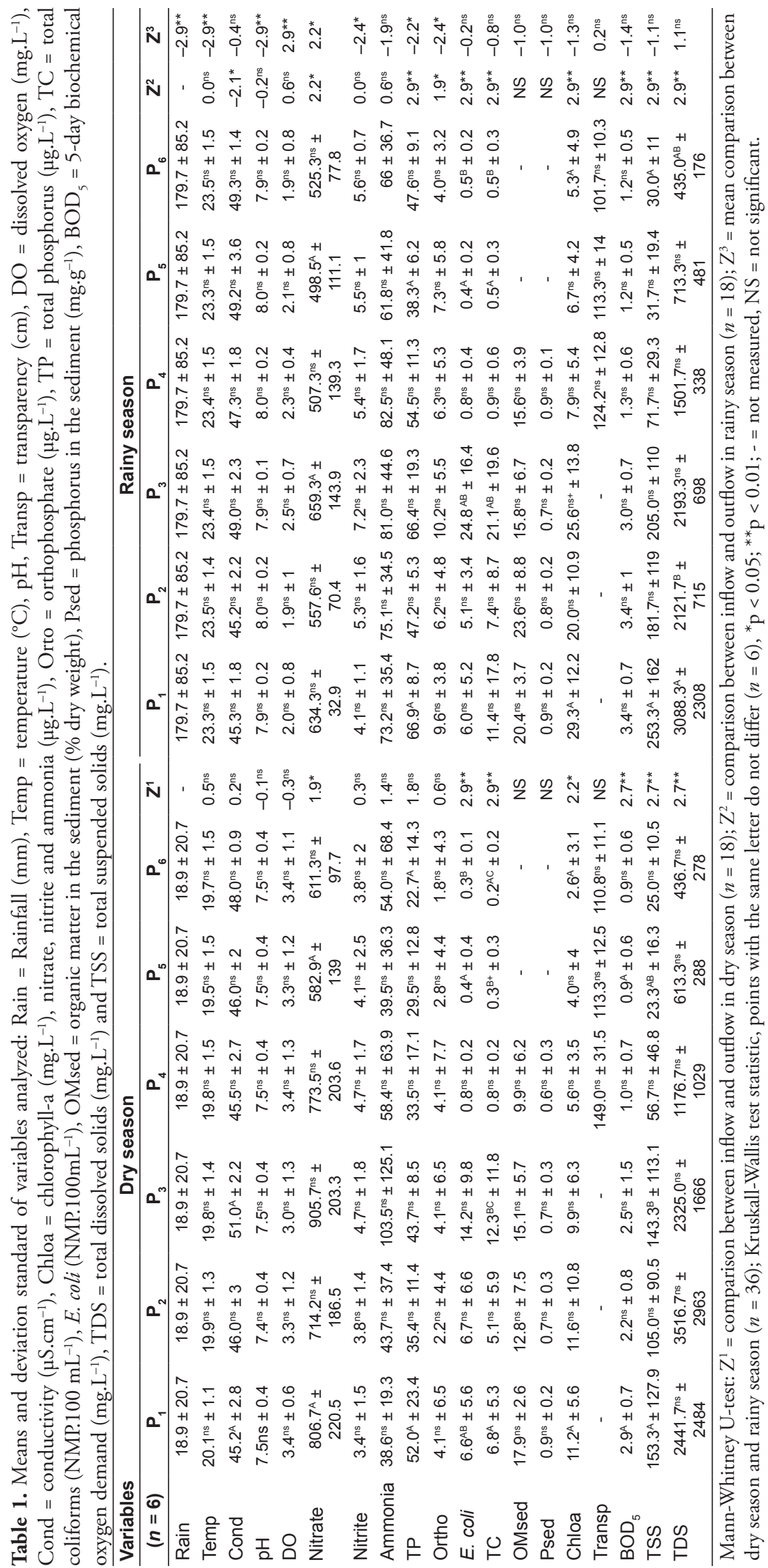


in the sediment had a higher concentration at $\mathrm{P}_{1}$ $\left(0.9 \mathrm{mg} \cdot \mathrm{g}^{-1}\right)$ and a lower one at $\mathrm{P}_{4}\left(0.6 \mathrm{mg} \cdot \mathrm{g}^{-1}\right)$ (Table 1). Water transparency was higher at $\mathrm{P}_{4}$ $(149 \mathrm{~cm})$ and lower at $\mathrm{P}_{6}(101 \mathrm{~cm})$ (Table 1).

Chlorophyll-a concentration differed significantly $(\mathrm{p}<0.05)$ for $\mathrm{Z}^{1}$ and $\mathrm{Z}^{2}$, which revealed a higher association of phytoplankton due to the inflow of nutrients. Significant difference $(p<0.05)$ was detected between $\mathrm{P}_{1}$ and $\mathrm{P}_{6}$ in the two seasons, with $11.2 \mu \mathrm{g} . \mathrm{L}^{-1}$ and $2.6 \mu \mathrm{g} . \mathrm{L}^{-1}$ in the dry season and $29.3 \mu \mathrm{g} . \mathrm{L}^{-1}$ and $5.3 \mu \mathrm{g} . \mathrm{L}^{-1}$ in the rainy season, with the highest concentrations at $\mathrm{P}_{1}$ (Table 1).

$\mathrm{BOD}_{5}$, TDS and TSS rates were significantly different $(\mathrm{p}<0.05)$ for $\mathrm{Z}^{1}$ and $\mathrm{Z}^{2}$ and showed that macrophytes and allochthonous material caused an increase in organic matter within the environment. Significant differences $(\mathrm{p}<0.05)$ in $\mathrm{BOD}_{5}$ only occurred between $\mathrm{P}_{1}\left(2.9 \mathrm{mg} . \mathrm{L}^{-1}\right)$ and $\mathrm{P}_{5}\left(0.9 \mathrm{mg} . \mathrm{L}^{-1}\right)$ during the dry season. With regard to TSS, significant difference $(\mathrm{p}<0.05)$ occurred between $\mathrm{P}_{1}\left(153.3 \mathrm{mg} . \mathrm{L}^{-1}\right), \mathrm{P}_{3}\left(143.3 \mathrm{mg} . \mathrm{L}^{-1}\right)$ and $\mathrm{P}_{5}\left(23.3 \mathrm{mg} . \mathrm{L}^{-1}\right)$ during the dry season, and between $\mathrm{P}_{1}$ (253.3) and $\mathrm{P}_{6}\left(30 \mathrm{mg} \cdot \mathrm{L}^{-1}\right)$ during the rainy season (Table 1).

High rates of Trophic State Index (Table 2) occurred at the inflow area of runoff water. Riparian vegetation did not adequately constrain flooding from the pastureland surrounding the pond. Consequently, an increase in the concentrations of phosphorus and other nutrients occurred, favoring vegetal development, especially at the supereutrophic points $\mathrm{P}_{1}$ and $\mathrm{P}_{3}$ respectively during the dry and rainy seasons. Throughout the experimental period $\mathrm{P}_{4}$ was mesotrophic due to its transitional condition between water inflow and outflow (Table 2).

\section{Discussion}

Some factors caused variations among the sampling points and between the dry and rainy seasons. The capybaras affected the rates of suspended material, $\mathrm{BOD}_{5}$ and fecal coliforms in the water, even though rainfall was a determining factor in nutrient concentration, $\mathrm{pH}$ and dissolved oxygen in the pond and influenced directly the trophic state.

Distinct conditions between the dry and rainy seasons determined changes in leaves, biomass and survival of macrophytes (Touchette et al., 2010). In current study, rainfall affected the inflow of nutrients into the pond, increased the environmental trophic load and impaired the quality of water supply for the aquaculture system.

Insignificant $\mathrm{pH}$ oscillations in water are frequent in small ponds with macrophytes and the presence of sediment and plants determine low rates in dissolved oxygen and electrical conductivity with slight acidification of the water (Crispim et al., 2009). However, in current study rainfall was the main factor that increased $\mathrm{pH}$ of the water column.

Mean dissolved oxygen concentration remained below $3.4 \mathrm{mg} . \mathrm{L}^{-1}$ during the dry season and $2.5 \mathrm{mg} . \mathrm{L}^{-1}$ during the rainy season. This fact has been reported by Takamura et al. (2003), who reported that high macrophyte densities decreased the penetration of light and the inflow of allochthonous material during the rainy season, increased water turbidity and impaired the photosynthesis activities of the phytoplankton.

Although fecal bacteria are frequently found in environments with high nutrient concentrations (Wilcock et al., 2011), organic carbon is a determining factor for the development of bacteria in water. Principal components analysis in current study revealed the relationship between fecal coliforms and rainfall, suspended matter, nutrients in the water, organic matter and phosphorus in the sediment.

Aquatic plants are greatly recommended because of their high efficiency in removing coliforms, with the subsequent simplifying and lowering of costs in water treatment (Kacar and Gungor, 2010) and a decrease in risks for public health, as recommended by several international organizations (Agatemor and Okolo, 2007).

Current data demonstrated that local fauna (capybara) influenced the rate of fecal bacteria,

Table 2. Trophic state at sampling points $\left(\mathrm{P}_{1}-\mathrm{P}_{6}\right)$ during the dry and rainy seasons.

\begin{tabular}{|c|c|c|c|c|c|}
\hline Season & Point & TSI & Season & Point & TSI \\
\hline \multirow[t]{6}{*}{ Dry } & $P_{1}$ & Supereutrophic & Rainy & $P_{1}$ & Eutrophic \\
\hline & $\mathrm{P}_{2}$ & Eutrophic & & $\mathrm{P}_{2}$ & Eutrophic \\
\hline & $\mathrm{P}_{3}$ & Eutrophic & & $\mathrm{P}_{3}$ & Supereutrophic \\
\hline & $\mathrm{P}_{4}$ & Mesotrophic & & $\mathrm{P}_{4}$ & Mesotrophic \\
\hline & $P_{5}$ & Oligotrophic & & $P_{5}$ & Mesotrophic \\
\hline & $P_{6}$ & Oligotrophic & & $\mathrm{P}_{6}$ & Mesotrophic \\
\hline
\end{tabular}


$\mathrm{BOD}_{5}$, suspended solids and conductivity. The capybaras in the environment under analysis deteriorated the water quality by fecal coliforms and sediment suspensions.

Points $\mathrm{P}_{1}, \mathrm{P}_{2}$ and $\mathrm{P}_{3}$ are greatly related to chlorophyll-a, total phosphorus and electrical conductivity in the water, due to the inflow of nutrients, runoff of pastureland near the pond, and to animals that affect sediment suspension in shallow environments. Sediment re-suspension may increase phosphorus rates in the water and enhance the increase of phytoplankton in many aquatic environments (Thomaz et al., 2007).

Although a moderate trophic state in water reservoirs may benefit the aquatic organism populations due to an increase in nutrient availability for phytoplankton and zooplankton communities, it may also be a liability because of the supply of nutrients to the toxic microorganisms in the environment (Takenaka et al., 2006). Current study showed that water outflows would become oligotrophic and mesotrophic if the capybaras and the surrounding area were not properly managed. In fact, the trophic status would increase in points $\mathrm{P}_{5}-\mathrm{P}_{6}$ in the near future.

Water plants may contribute towards an increase in eutrophication during the decomposition processes (Thomaz and Bini, 2003). Macrophytes in current study became biological filters and improved the environmental conditions of points $\mathrm{P}_{1}, \mathrm{P}_{2}$ and $\mathrm{P}_{3}$ at the water inflow in the pond and for the water outflow at $\mathrm{P}_{5}-\mathrm{P}_{6}$ that supply the several ponds of the aquaculture farm.

The system under analysis is directly influenced by rainfall, local fauna and the lack of adequate management around the pond. Water quality during the dry season was adequate for supply even though the nutrients, fecal coliforms and trophic state index increased during the rainy season and dissolved oxygen concentration decreased because of the high load of allochthonous material from the surrounding area. Water deterioration may affect the production capacity and the quality of organisms of the aquaculture farm. The control of allochthonous material from the cattle-raising (cattle- and sheep-breeding) area introduced into the pond by leaching, the isolation of animals that deteriorate water quality and the maintenance of macrophytes in the pond are recommended.

\section{Acknowledgements}

The authors would like to thank FAPESP (Process n. 2008/54954-7) for funding and CAPES for the scholarship. They also thank the working group of the Limnology and Plankton Production Laboratory of CAUNESP.

\section{References}

AGATEMOR, C. and OKOLO, PO. 2007. University of Benin water supply system: Microbiological and physical-chemical assessments. Environmentalist, vol. 27, no. 2, p. 227-239. http://dx.doi.org/10.1007/ s10669-007-9000-4

ANDERSEN, JM. 1976. An ignition method for determination of total phosphorus in lake sediments. Water Research, vol. 10, p. 329-331. http://dx.doi. org/10.1016/0043-1354(76)90175-5

BRAINWOOD, MA. and MAHESHWARI, SBS. 2004. Temporal variations in water quality of farm dams: impacts of land use and water source. Agricultural Water Management, vol. 70, no. 2, p. 151-175. http:// dx.doi.org/10.1016/j.agwat.2004.03.006

BOYD, CE. and TUCKER, CS. 1992. Pond aquaculture water quality management. Alabama: Agricultural Experiment Station. p. 183.

CALIJURI, MC., CUNHA, DGF., QUEIROZ, LA. and MIWA, ACP. 2008. Nutrients and chlorophyll-a concentrations in tropical rivers of Ribeira de Iguape Basin, SP, Brazil. Acta Limnologica Brasiliensia, vol. 20, no. 2, p. 131-138.

CRISPIM, MC., VIEIRA, ACB., COELHO, SFM. and MEDEIRO, AMA. 2009. Nutrient uptake efficiency by macrophyte and biofilm: practical strategies for small-scale fish farming. Acta LimnologicaS Brasiliensia, vol. 21, no. 4, p. 387-391.

GOLTERMAN, HL., CLYMO, RS. and OHNSTAD, MAM. 1978. Methods for physical and chemical analysis of freshwater. London: Blackwell Sci. Publ. p. 213.

GREENBERG, AE., CLESCERI, LS. and EATON, AD. 1992. Standard methods for examination of water wastewater. 18th ed. Washington: American Public Health Association. p. 1100.

JONIAK, T., KUCZYNSKA-KIPPEN, N. and NAGENGAST, B. 2007. The role of aquatic macrophytes in microhabitatual transformation of physical-chemical features of small water bodies. Hydrobiologia, vol. 584, no. 1, p. 101-109. http:// dx.doi.org/10.1007/s10750-007-0595-8

KACAR, A. and GUNGOR, F. 2010. Comparison of fecal coliform bacteria before and after wastewater treatment plant in the Izmir Bay (Eastern Aegean Sea). Environmental Monitoring Assessment, vol. 162, no. 1-4, p. 355-363. PMid:19234749. http://dx.doi. org/10.1007/s10661-009-0801-4

KOROLEFF, F. 1983. Determination of ammonia. In GRASSHOFF, K., EHRHARDT, $M$. and KREMLING, K. Methods of seawater analysis: second, revised and extended edition. German: Verlag Chemie. p. 126-133.

LISHAWA, SC., ALBERT, DA. and TUCHMAN, NC. 2010. Water level decline promotes Typha $x$ 
glauca establishment and vegetation change in great lakes coastal wetlands. Wetlands, vol. 30, no. 6, p. 1085-1096. http://dx.doi.org/10.1007/s13157010-0113-z

MANLY, BFJ. 1986. Multivariate Statistical Methods. London: Chapman Hall. p. 159.

MEADOR, MR. and GOLDSTEIN, RM. 2003. Assessing water quality at large geographic scales: Relations among land use, water physicochemistry, riparian condition and fish community structure. Environmental Management, vol. 31, no. 4, p. 504-517. PMid:12677296. http://dx.doi. org/10.1007/s00267-002-2805-5

NEILL, H., GUTIERREZ, M. and ALEY, T. 2004. Influences of agricultural practices on water quality of Tumbling Creek cave stream in Taney County, Missouri. Environmental Geology, vol. 45, no. 4, p. 550-559. http://dx.doi.org/10.1007/s00254003-0910-2

NUSCH, EA. 1980. Comparison of different method for chlorophyll and pheopigments determination. Archiv für Hydrobiologie, vol. 14, p. 14-36.

PEEL, MC., FINLAYSON, BL. and McMAHON, TA. 2007. Updated world map of the KöppenGeiser climate classification. Hydrology and Earth System Sciences, vol. 11, p. 1633-1644. http://dx.doi. org/10.5194/hess-11-1633-2007

PLUMMER, JD. and LONG, SC. 2007. Monitoring source water for microbial contamination: evaluation of water quality measures. Water Research, vol. 41, no. 16, p. 3716-3728. PMid:17560623. http:// dx.doi.org/10.1016/j.watres.2007.05.004

RUGGIERO, A., SOLIMINI, AG. and CARCHINI, G. 2003. Nutrient and chlorophyll-a temporal patterns in eutrophic mountain ponds with contrasting macrophyte coverage. Hydrobiologia, vol. 506-509, no. 1-3, p. 657-663. http://dx.doi. org/10.1023/B:HYDR.0000008549.04464.cc

SIEGEL, S. 1975. Non-Parametric Statistics for the behavioral sciences. São Paulo: McGraw-Hill do Brasil. p. 350.

SILVA, AMM. and SACOMANI, LB. 2001. Using chemical and physical parameters to define the quality of Pardo River water (Botucatu SP Brazil). Water Research, vol. 35, no. 6, p. 1609-1616. http://dx.doi. org/10.1016/S0043-1354(00)00415-2

SIPAÚBA-TAVARES, LH., OLIVEIRA, DBS., CASTAGNOLLI, MC., BACHION, MA. and DURIGAN, JG. 1991. Estudo batimétrico e morfométrico em represas. Ciência Zootécnica, vol. 6, no. 1, p. 10-12.

SIPAÚBA-TAVARES, LH. 2006. Aspectos limnológicos de um viveiro utilizado como abastecimento de água para sistemas de aquicultura. Boletim Técnico do CEPTA, vol. 19, p. 59-64.
SIPAÚBA-TAVARES, LH., GUARIGLIA, CST. and BRAGA, FMS. 2007. Effects of rainfall on water quality in six sequentially disposed fishponds with continuous water flow. Brazilian Journal of Biology, vol. 67, no. 4, p. 643-649. PMid:18278315. http:// dx.doi.org/10.1590/S1519-69842007000400008

SUDING, KN., GROSS, KL. and HOUSEMAN, GR. 2004. Alternative states and positive feedbacks in restoration ecology. Trends in Ecology and Evolution, vol. 19, no. 1, p. 46-53. PMid:16701225. http:// dx.doi.org/10.1016/j.tree.2003.10.005

TAGUCHI, K. and NAKATA, K. 2009. Evaluation of biological water purification functions of inland lakes using an aquatic ecosystem model. Ecological Modelling, vol. 220, no. 18, p. 2255-2271. http:// dx.doi.org/10.1016/j.ecolmodel.2009.05.007

TAKAMURA, N., KADONO, Y., FUKUSHIMA, M., NAKAGAWA, M. and KIM, BHO. 2003. Effects of aquatic macrophytes on water quality and phytoplankton communities in shallow lakes. Ecological Research, vol. 18, no. 4, p. 381-395. http:// dx.doi.org/10.1046/j.1440-1703.2003.00563.x

TAKENAKA, RA., SOTERO-SANTOS, RB. and ROCHA, O. 2006. Water quality assessment by Ecotoxicological and Limnological Methods in Water Supplies, Southeast Brazil. Ecotoxicology, vol. 15, no. 7, p. 73-82. PMid:16374663.

THOMAZ, SM., BINI, LM. and BOZELLI, RL. 2007. Floods increase similarity among aquatic habitats in river-floodplain systems. Hydrobiologia, vol. 579, no. 1, p. 1-13. http://dx.doi.org/10.1007/s10750006-0285-y

THOMAZ, SM. and BINI, LM. 2003. Ecologia e manejo de macrófitas aquáticas. Maringá: Eduem. p. 341.

TOLEDO JUNIOR, AP., TALARICO, M., CHINEZ, SJ. and AGUDO, EG. 1983. A aplicação de modelos simplificados para a avaliação do processo de eutrofização em lagos e reservatórios tropicais. In Anais do $12^{\circ}$ Congresso Brasileiro de Engenharia Sanitária e Ambiental, 1983. Camburiú. p. 34.

TOUCHETTE, BW., IANNACONE, LR., TURNER, G. and FRANK, A. 2010. Ecophysiological responses of five emergent-wetlands plants to diminished water supply: an experimental microcosm study. Aquatic Ecology, vol. 44, no. 1, p. 101-112. http://dx.doi. org/10.1007/s10452-009-9246-7

WILCOCK, RJ., NASH, D., SCHMIDT, J., LARNED, ST., RIVER, MR. and FEEHAN, P. 2011. Inputs of nutrients and fecal bacteria to freshwaters from irrigated agriculture: Cases studies in Australia and New Zealand. Environmental Management, vol. 48, no. 1, p. 198-211. PMid:21365272. http://dx.doi. org/10.1007/s00267-011-9644-1

ZAR, JH. Biostatistical Analysis. New Jersey: Prentice-Hall Inc., 1999. p. 620. 